\title{
Soil Engineering Properties Improvement by Utilization of Cut Waste Plastic and Crushed Waste Glass as Additive
}

\author{
Achmad Fauzi, Zuraidah Djauhari, and Usama Juniansyah Fauzi
}

\begin{abstract}
In general, clayey soil was used as soil material or embankment material for increasing road way level before road structure being constructed. Some types of clay are expansive soil, its have been contributing to pavement failures and subsequently causing increased annual maintenance expenditure of the road. The pavements design/redesign methods are found to be the primary cause of these failures. Thus, it is quite important to propose the utilization of waste plastic and waste glass on soil subgrade improvement and then contributing decreased of pavement failures.

This paper was evaluated the engineering properties on utilizing waste plastic High Density Polyethylene (HDPE) and waste crushed glass as additive on subgrade improvement. The research were conducted soil engineering properties, standard compaction, four days soaked California Bearing Ratio (CBR) and Triaxial test to some clayey soil samples from various sites in Kuantan. The 4 days soaked CBR of clayey soil samples were prepared at optimum water content. The variation of additive content on stabilized soil: $4 \%, 8 \%, 12 \%$ by dry total weight of soil sample respectively. The chemical element was investigated by Integrated Electron Microscope and Energy-Dispersive X-Ray Spectroscopy (SEM-EDS). Test result were shown that engineering properties and CBR on stabilized clayey samples were increased when the content of waste HDPE and Glass were increased.
\end{abstract}

Index Terms-Engineering properties, waste plastic, waste glass, soil improvement.

\section{INTRODUCTION}

The performance of pavement depends upon the quality of soil-subgrade. A stable soil-subgrade and properly draining pavement helped to produce a long-lasting pavement. Subgrade soil provides support to the remainder of the pavement system. The quality of the subgrade would be greatly influence the pavement design and the service life of the pavement. Road running in expansive soils areas are known for bad condition and unpredictable behavior for which the nature of the soil contributes to some extent. The failures of pavement, in form of heave, depression, cracking and unevenness are caused by the seasonal moisture variation in the subgrade soil. For many years, researchers have

Manuscript received July 9, 2014; revised September 10, 2014. This research was financially supported by University Malaysia Pahang (UMP) under Research Grand, RDU 110392.

Achmad Fauzi is with the Faculty of Civil Engineering and Earth Resources, University Malaysia Pahang, Lebuh Raya Tun Razak 26300, Gambang, Kuantan, Malaysia (e-mail: achmad@ump.edu.my)

Zuraidah Djauhari is with the Faculty of Engineering, IGM University, Palembang, Indonesia (e-mail: fauzi_phd@yahoo.com)

Usama Juniansyah Fauzi is with Graduate School of Civil Engineering, Doctoral Course, University of Tokyo, Japan (e-mail: juniansyahfauzi@gmail.com) studied the expansive soil-subgrades in an effort to determine the most appropriate methods of design and construction practices where these soils cannot be avoided. Furthermore, there has been significant amount of research on soil-subgrade improvement techniques to construct a uniform and stable pavement on expansive soils or highly plasticity soil as classified A-7-6 by AASHTO Classification System [1]. One approach is to use chemical to stabilize the clay sub grade. Instead of using chemical product, reused material may offer more economical alternatives for a wide range application of soil stabilization. Subgrade stabilization of Kuantan clayey soil besides to improve the engineering properties, make the upper part of road structure become stable and decrease pavement thickness [2]-[7].

Now days, many of the wastes produced today will remain in the environment for hundreds thousands of years. The creation of non-decaying waste materials combined with a growing consumer population has resulted in a waste disposal crisis. One solution to this crisis lies in recycling and reused waste into useful products. In general the engineering properties of soil subgrade were high plasticity material were improved by using waste material as stabilizer [4]-[12]. Soil reinforcement with randomly distributed fiber is another approach which may increase the internal cohesion of soil, improved the shear strength parameter, compressive strength and bearing capacity.

In this research, the utilization of cutting waste HDPE and waste crushed glass as additive for subgrade improvement were investigated.

\section{MATERIAL AND METHOD}

\section{A. Soil and Material Additive}

Two types of clayey soil from random places in Kuantan were used as soil samples. Waste cutting HDPE and crushed waste glass were used as additives in stabilized soil.

\section{B. Experimental Program and Testing}

First phase: soil sample and material additive were collected and tested. Second phase: stabilized soil design and tested. The variation of additive contents on stabilized soil were $4 \%, 8 \%, 12 \%$ by dry total weight of soil sample respectively. Third phase: data analyzed and paper presenting.

The engineering properties and strengths testing were conducted base on BS 1990 1377-4 [8]. The Sieve Analysis, Atterberg Limit, Specific Gravity, Standard Compaction, Soaked California Bearing Ratio (CBR), Triaxial were tested to the original clayey and stabilized clayey soil samples. The grain size for clayey soil retained a sieve $0.075 \mathrm{~mm}$ and 
passed sieve $0.075 \mathrm{~mm}$ were tested by sieve shaker and CILAS 1180 Particle Size Stabilizer respectively. The chemical element for clayey were investigated by Integrated Electron Microscope and Energy-Dispersive X-Ray Spectroscopy (SEM-EDS).

\section{RESUlT AND DisCUSSION}

\section{A. Index Properties}

The index properties, particle size distribution curve clayey samples were shown in Table I and Fig. 1 respectively.

TABLE I: THE ENGINEERING PROPERTIES OF SOIL SAMPLES

\begin{tabular}{|c|c|c|c|c|c|c|c|c|c|c|}
\hline \multirow{2}{*}{ SAMPLE } & \multirow{2}{*}{ DESCRIPTION } & \multirow{2}{*}{ CLASSFICATION } & \multicolumn{4}{|c|}{ FINER/PASSING SIEVE NO. (\%) } & \multirow{2}{*}{ LL $(\%)$} & \multirow{2}{*}{ PI (\%) } & \multirow{2}{*}{ Gs } & \multirow{2}{*}{ SL $(\%)$} \\
\hline & & & 10 & 40 & 200 & $2 \mu \mathrm{m}$ & & & & \\
\hline $\mathrm{R} 2$ & White clayey silt & A-7-6 & 91.74 & 71.99 & 37.37 & 1.14 & 34.6 & 17.7 & 2.58 & 6.73 \\
\hline R24 & $\begin{array}{l}\text { Gray whitish silty } \\
\text { clay }\end{array}$ & A-6 & 83.12 & 63.03 & 50.09 & 1.78 & 35 & 10.04 & 2.53 & 2.00 \\
\hline
\end{tabular}

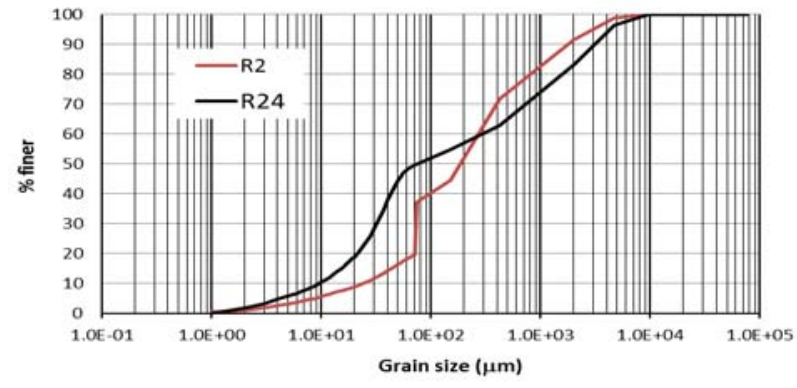

Fig. 1. Particles size distribution curve of soil samples.

Clayey soil samples R2 and R24 were high and medium plasticity classified as clayey soil or A-7-6 (or A-6) by AASHTO Classification System [1]. The R2 soil cannot be used directly as soil-subgrade or embankment material for road subgrade, these material have to avoid. If the used of soils cannot reasonably avoided, such material shall be used only on bottom portion of embankment before sub-base course.

The Scanning electron of R2 and R24 samples were tested by SEM-EDS shown in Fig. 2, Fig. 3 and Table II.

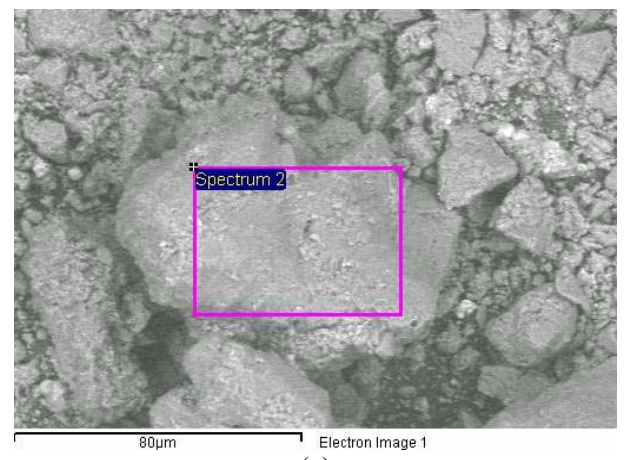

(a)

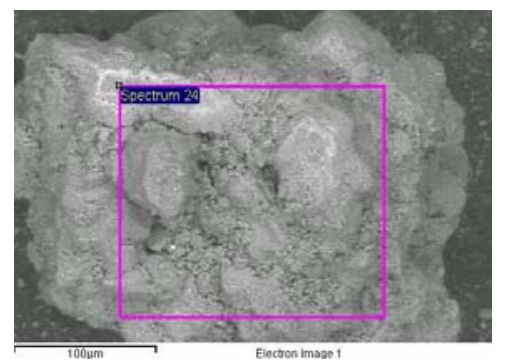

(b)

Fig. 2. (a) Scanning Electron of R2; (b) Scanning Electron of R24 sample

The R2 and R24 samples were contented of C, O, Al, Si, K, $\mathrm{Fe}$ and Ti minerals and mineral $\mathrm{O}$ were the highest content omong them
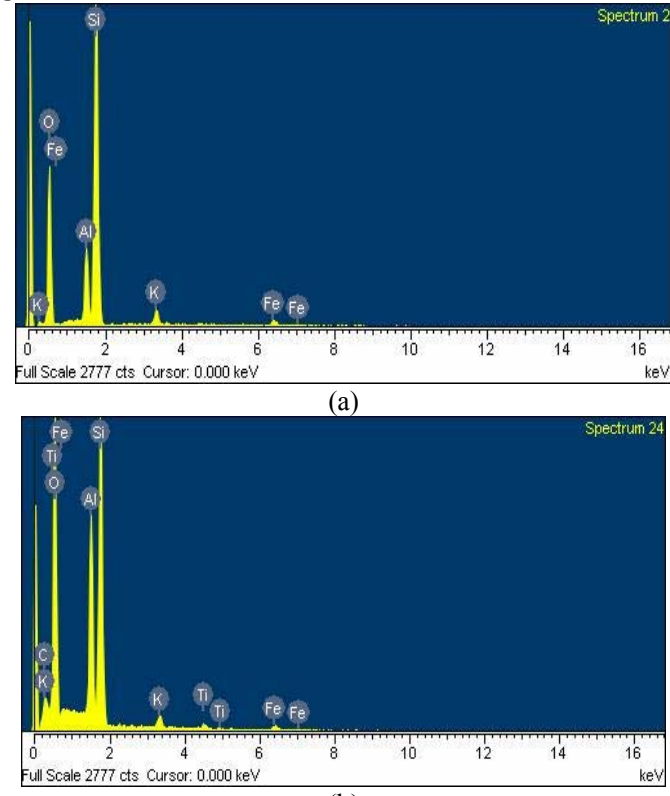

(b)

Fig. 3. (a) Energy Dispersive X-Ray of R2; (b) Energy Dispersive X-Ray R24 sample

TABLE II: Mineral CONTAINED IN SIDE OF SOIL SAMPLES

\begin{tabular}{|c|c|c|c|c|c|c|c|c|}
\hline \multirow{2}{*}{ Sample } & \multicolumn{7}{|c|}{ Mineral/Element Content (\% Weight) } \\
\cline { 2 - 9 } & $\mathrm{C}-\left(\mathrm{C}_{2} \mathrm{CO}_{3}\right)$ & $\mathrm{O}-\left(\mathrm{SiO}_{2}\right)$ & $\mathrm{Al}_{-\mathrm{Al}_{2} \mathrm{O}_{3}}$ & $\mathrm{Si}-\left(\mathrm{SiO}_{2}\right)$ & $\mathrm{K}-(\mathrm{MAD})$ & $\mathrm{Ti}-(\mathrm{Ti})$ & $\mathrm{Fe}-(\mathrm{Fe})$ & $\mathrm{S}-(\mathrm{FeS})_{2}$ \\
\hline $\mathrm{R} 2$ & - & 54.21 & 6.82 & 34.33 & 2.23 & - & 2.41 & - \\
\hline $\mathrm{R} 24$ & 7.48 & 59.83 & 11.17 & 18.82 & 0.92 & 0.58 & 1.20 & - \\
\hline
\end{tabular}

When the weak soil was mixed with additive in the presence of reaction with water, chances towards a new element was high. Hence, Fig. 3 was illustrated the energy dispersive X-ray characterization for optimum design of mixed soil samples. The presence of other elements such as $\mathrm{S}$, $\mathrm{K}$ and $\mathrm{Ca}$ could also be observed from the figure. Table II has listed the components that could be found inside the natural soil. The most prevalent compound present in this mixture soil was $\mathrm{S}_{\mathrm{i}} \mathrm{O}_{2}$ (54-60\%). As observed, the bonding of silica and alumina had given major distribution effects among the elements. However, some elements needed to be absent for good bonding with other elements to form a strong 
compound to stabilize weak soil.

The relation between liquid limit (LL) with plasticity index (PI) for R2, R24 samples were shown in Fig. 4 (a) and Fig. 4(b) respectively. LL and PI values of R2, R24 samples were decreased when increased of HDPE and Glass content in soil mixed.

The result of the tested were shown that engineering properties of samples improved when utilized the waste HDPE and Glass adding in soil mixed, increased of PI about $10 \%$ for R24 and 2\% for R2 samples respectively.

Activity (A) of R2, R24 soil samples were 15.53 and 5.85 respectively. A of R2, R24 were greater than 1.4, its mean active soil with clay mineral were Montmorillinite. Montmorillinite is the main constituent of Bentonite, derived by weathering of volcanic ash and active mineral. The active soil and can expand by several times its original volume when it comes in contact with water, resulting very weak bonding and high swelling. Such material should be avoid or shall be used only on bottom portion of embankment before sub-base course or should be stabilized to improve the engineering properties [2]-[6].

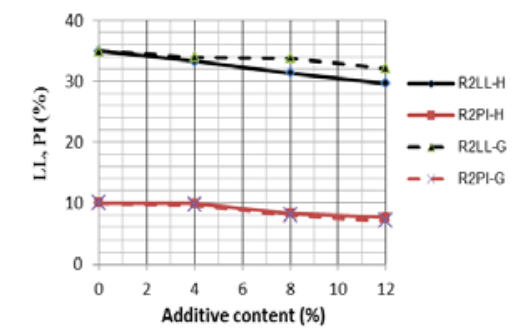

(a)

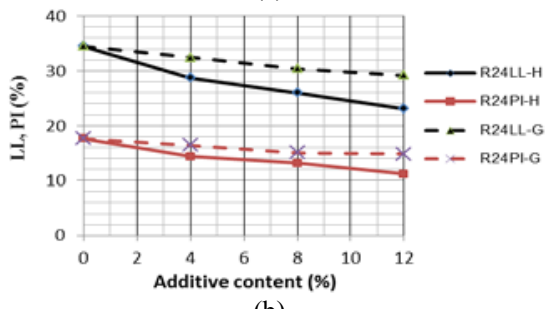

(b)

Fig. 4. (a) The relation between LL, PI with additive for R2; (b) The relation between LL, PI with additive for R24 sample.

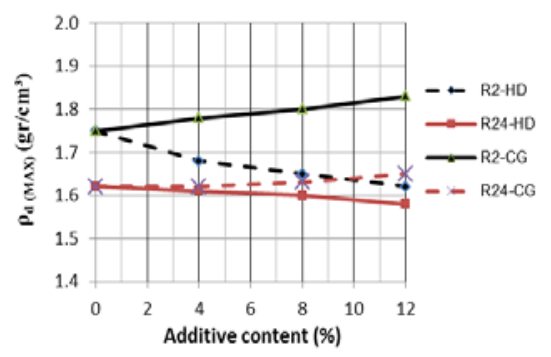

(a)

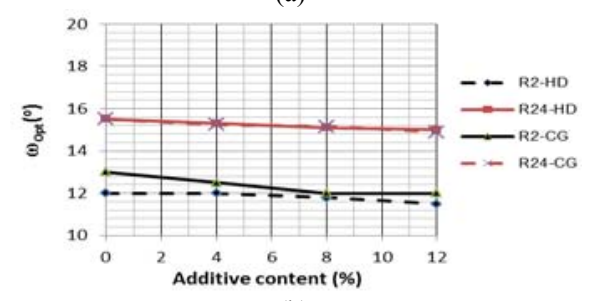

(b)

Fig. 5. (a) The relation between $\omega_{\text {opt. }} \rho_{d \max }$ of R2 and R24 samples with additive content; (b) The relation between $\omega_{\text {opt }}$. of R2 and R24 with additive content.

\section{B. Compaction Properties}

The relationship between the Optimum Water Content $\left(\omega_{\text {opt }}\right)$ with Maximum Dry Density $\left(\rho_{d}\right.$ max. $)$ and the relationship between were shown in Fig. 5 (a) and Fig. 5(b) respectively. From Fig. 5, the values of R2 and R24 $\rho_{\text {dmax }}$ stabilized soil with HDPE were decreased and increased respectively when HDPE content increased. The R2 and R24 $\rho_{d \max }$ stabilized soil with Glass were decreased when increased of Glass content. The increased of maximum dry density in stabilized samples mean compaction properties were increased. The values of $\omega_{\text {opt }}$. R2 and R24 stabilized samples were decreased when increased of waste HDPE and Glass content.

The compaction properties were increased until $12 \%$ additive content, so waste cutting HDPE and crushed glass can utilized in soil stabilization.

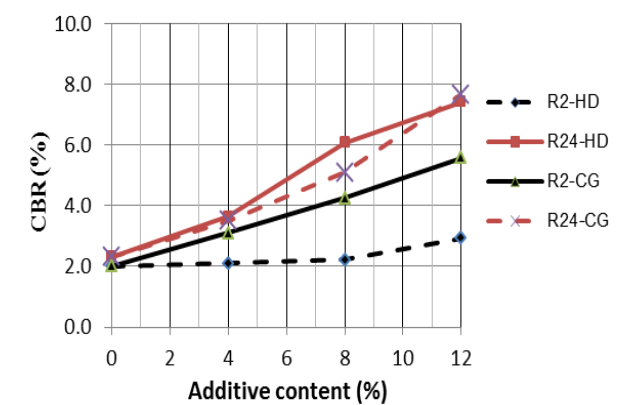

Fig. 6. The relation between CBR stabilized samples of R2, R24 with additive content.

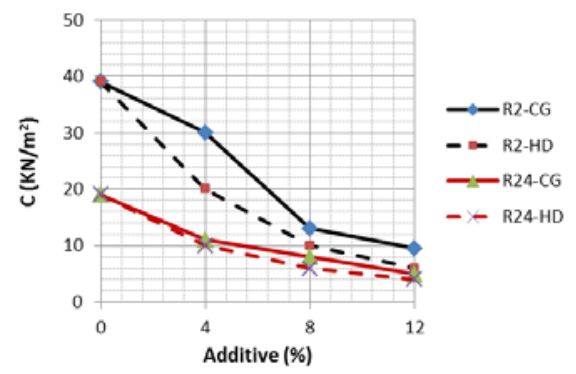

(a)

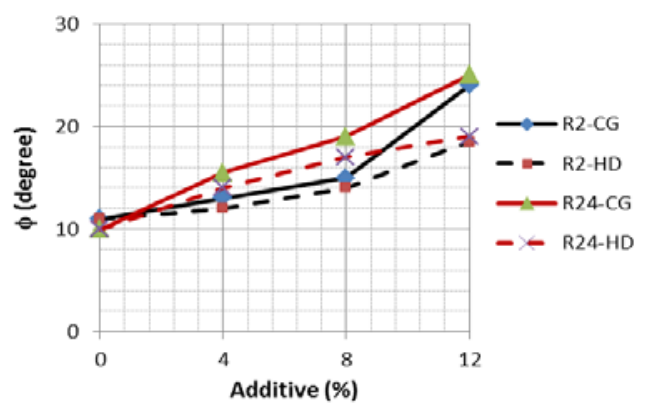

(b)

Fig. 7. (a) The relation between c with additive content; (b) The relation between $\phi$ and additive content.

\section{California Bearing Ratio (CBR)}

The clayey and stabilized samples were prepared at optimum water content due to field compaction carried out base on this value. The relation between $\omega_{o p t}$. and $\rho_{d \text { max }}$ of R2 and R24 stabilized samples with waste HDPE/Glass content were shown in Fig. 6. R2 and R24 CBR values of stabilized clayey samples were increased when the waste HDPE and Glass content increased. The increased of R2 and R24 CBR 
stabilized with waste HDPE and Glass were 3 to $5 \%$ respectively.

\section{Shear Strength Parameter}

The shear strength parameters were obtained using the undrained-unconsolidation (UU) Triaxial test. The relation betweeen cohesion (c), friction angle $(\phi)$ of R2 and R24 samples with waste HDPE and Glass content were shown in Fig. 7.

For all samples were shown that the value of $\mathrm{c}$ and decreased and increased respectively when the content of waste HDPE and Glass were increased. It's mean that shear strength parameter were improved in stabilized soil samples. When the shear strength parameters were improved, the performance calculate of maximum critical high of road embankment were reached.

\section{CONCLUSION}

A conclusion R2 and R24 clayey soil samples were high and medium plasticity soil, classified as A-7-6 and A-6 based on AASHTO Classification System respectively. Its samples were active soil with $\mathrm{A}>1.40$ and clay minerals were Montmorillinite. The active soil can expand by several times its original volume when it comes in contact with water, very weak bonding and high swelling. The R2 soil sample should be avoid or shall be used only on bottom portion of embankment before sub-base course or should be stabilized to improve the engineering properties.

The engineering properties of stabilized clayey samples were improved:

1) The PI values were decreased when content of waste HDPE and Glass were increased.

2) The value of $\omega_{o p t}$ and $\rho_{\text {d.max }}$ were decreased and increased respectively when content of waste HDPE and Glass were increased.

3) The CBR values were increased when content of waste HDPE and Glass increased.

4) $C, \phi$ Values were decreased and increased respectively when content of waste HDPE and Glass were increased.

Utilization of waste HDPE and Glass were eliminates need for expensive borrow material and promotes cost saving through decreasing of pavement thickness, solving disposal problems.

Innovations for highway engineers employ sustainable engineering practice that met additional constraints in term of environmentally being sustainable.

\section{REFERENCES}

[1] American Association of State Highway and Transportation Official, Part II Test, thirteenth edition. USA: AASHTO, 1992.
[2] A. Fauzi and Z. Djauhari, "Comparison of the engineering properties and CBR of Kuantan and south sumatera stabilized clayey by using carper fiber mixed with lime," in Proc. the 6th Civil Engineering Conference in Asia Region, vol. 3, Jakarta, Indonesia, 2013.

[3] A. Fauzi, W. M. Nazmi, and Z. Djauhari, "Experimental study on subgrade stabilization of kuantan clay soil using HDPE mixed with lime," in Proc. the 4th REEEA Conference, Kuala Lumpur, Malaysia, 2013

[4] A. Fauzi, W. M. Nazmi, and U. J. Fauzi, "Sub grade stabilization of Kuantan clay by using lime, port land cement, fly ash, bottom ash," in Proc. the $3^{\text {rd }}$ Int. conference on Disaster Mitigation and Rehabilitation combined with the $5^{\text {th }}$ International conference on Geotechnical and Highway Engineering, Semarang, Indonesia, pp 500-506, 2011.

[5] A. Fauzi, U. J. Fauzi, and W. M. Nazmi, "Engineering quality improvement of Kuantan clay subgrade using recycling and reused Materiala as stabilizer," SciVerse Science Direct, Procedia Enginering, vol. 54 , pp. 675-689, 2013

[6] A. Fauzi, W. M. Nazmi, and Z. Djauhari, "Engineering utilization waste material as stabilizer on Kuantan clayey soil stabilization," SciVerse Science Direct, Procedia Enginering, vol. 53, pp. 42-47, 2013.

[7] A. Amadi, "Evaluation of change in index properties of lateritic soil stabilized with fly ash," Leonardo Journal of Practices and Technology, pp. 69-78, 2010.

[8] BS 1377-4 1990, Methods of Test for Soils for Civil Engineering purposes, part 4. Compaction-related Test. BSI, 1990.

[9] C. F. Yim and M. Y. Wey, "Comparison of the characteristics of bottom and fly ashes generated from various incinerations processed," Journal of Hazardous Materials B138, pp. 594-603, 2006.

[10] H. A. Lav, M. A. Lav, and A. B. Goktepe, "Analysis and design of a stabilized fly ash as pavement base material," Science Direct, vol. 85, pp. 2359-2370, 2006.

[11] S. Kolias, V. K. Rigopoulou, and A. Karahalios, "Analysis and design of a stabilized fly ash as pavement base material," Science Direct, vol. 27, pp. 2359-2370, 2004.

[12] A. Senol, B. Shafique, T. B. Edil, and C. H. Benson, "Use of class C fly ash for the stabilization of soft soil as sub base," ARI the Bulletin of the Istanbul Technical University, vol. 53, pp. 89-95, 2003

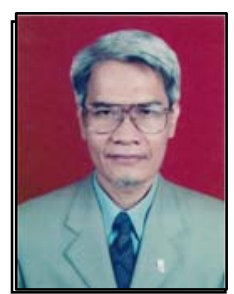

Achmad Fauzi was born on August 1, 1957 in Palembang, Indonesia (INA). He received his doctor in land management from University of Sriwijaya Palembang, INA in 2007, and he completed his master in civil engineering from University Niigata, Japan. He was post graduated in highway engineering from Bandung Institute Technology, INA and he received his bachelor in civil engineering from Sriwijaya University, INA in 1990, 1985 and 1983 respectively.

He have more than 30 year working experience as an engineer in various capacities in Government Sector involving mainly in highway and infra structure projects (at the directorate general of highway, Department of Public Work of Indonesia) and successfully as : 1) Project Manager some Highway Project; 2) Head of section; 3) Head of Sub Agency at South Sumatera Provincial of Highway Agency; 4) Head of Prabumulih City Public Works Agency At Government of Prabumulih City, South Sumatera Province. After retired in February 2009, He was a staff member of the Faculty of Civil Engineering and Earth Resources, University Malaysia Pahang in Kuantan, East Peninsular Malaysia until present as Assoc Professor in Geotechnical and Highway Engineering. His research interest: about soil mechanics, geotechnical for highway engineering and highway material, design, construction and supervision

Achmad is a member of Indonesian Road Development Association (IRDA) and Indonesian Engineer Association (PII). 